\title{
Influence of metasomatism on vanadium-based redox proxies for mantle peridotite
}

\author{
A.B. Woodland ${ }^{1 *}$, L. Uenver-Thiele ${ }^{1}$, H.-M. Seitz ${ }^{1}$
}

Abstract

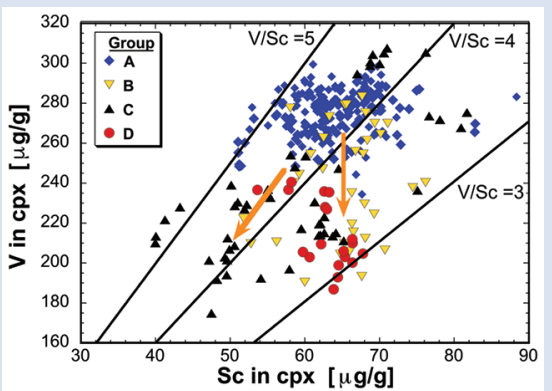

The multi-valence nature of vanadium means that its geochemical behaviour will be $\mathrm{fO}_{2}$-dependent, so that its concentration or V/Sc (or V/Ga), can serve as proxies for oxidation state in mantle peridotites. Compared to $\mathrm{Fe}^{3+} / \mathrm{Fe}^{2+}$-based equilibria, such trace elements may be less sensitive to metasomatic processes. To investigate these systematics, we have measured V, Sc, Ga and $\mathrm{Fe}^{3+}$ contents in clinopyroxene from well-characterised spinel peridotite xenoliths from the Massif Central, France. These samples were metasomatised by a variety of agents with different oxidation states.

$\mathrm{V}$ contents can be modified by metasomatic interactions, and other geochemically similar elements including Sc and Ga can also be added, removed or remain constant. A link between V/Sc and $\mathrm{Fe}^{3+}-\mathrm{Fe}^{2+}$ equilibria is apparent. Partial removal of $\mathrm{V}$ is caused by different metasomatic agents; the common factor is that all agents were significantly more oxidised than the initial ambient mantle peridotite. This extraction can be understood by a decreasing partition coefficient for $\mathrm{V}$ for $\Delta \log f \mathrm{O}_{2}>\sim \mathrm{FMQ}-2$. Considering that mineral/melt partitioning of $\mathrm{V}$ decreases similarly for all peridotite minerals, the bulk-rock V/Sc will also change during relatively oxidising metasomatic interactions and mirror the results obtained for clinopyroxene.

\section{Introduction}

The oxidation state of the Earth's upper mantle is an important parameter that influences many geochemical processes, including partial melting and whether carbon can migrate as carbonate in a metasomatising fluid/melt or is sequestered as graphite/diamond. Therefore, constraining this parameter is an essential goal in petrology. At the conditions of the Earth's interior, free oxygen is an insignificant component, even though oxidation state is usually expressed in terms of oxygen fugacity $\left(f \mathrm{O}_{2}\right)$. Instead, the reigning $f \mathrm{O}_{2}$ is related to the bulk $\mathrm{Fe}^{3+} / \sum \mathrm{Fe}$ via ferric-ferrous equilibria involving mantle silicates and oxides. The $\mathrm{Fe}^{3+}$-partitioning between these phases is determinant, since this controls the activities of the $\mathrm{Fe}^{3+}$-bearing components involved in these equilibria. Thus, the $\mathrm{Fe}^{3+}$ content of key phases (spinel, garnet, or clinopyroxene) reflects the oxidation state. However, $\mathrm{Fe}^{3+}$ contents will be continually modified through interactions with migrating melts/fluids or juxtaposition of rock domains with different $f_{2} \mathrm{O}_{2}$ s. In practice, the $f \mathrm{O}_{2}$ determined for a given rock represents the most recent state of equilibration.

The multi-valence nature of vanadium $\left(\mathrm{V}^{2+}, \mathrm{V}^{3+}, \mathrm{V}^{4+}\right.$, $\mathrm{V}^{5+}$ ) means that its geochemical behaviour is influenced by the prevailing $\mathrm{fO}_{2}$ and that its concentration could serve as a proxy for oxidation state in mantle peridotites (e.g., Canil and Fedortchouk, 2000; Canil, 2002; Lee et al., 2003). It has been suggested that $\mathrm{V}$ concentrations or V/Sc of peridotites are less sensitive to metasomatic processes than $\mathrm{Fe}^{3+} / \mathrm{Fe}^{2+}$ and thus can "see through" such interactions and provide a picture of oxidation state during the last episode of partial melting (Lee et al., 2003 , 2005). The advantage of using V/Sc, or similarly V/Ga, is that while only $\mathrm{V}$ is redox-sensitive, all three are mildly incompatible (e.g., Canil, 2004; Mallmann and O'Neill, 2009). Thus, variations in $\mathrm{V} / \mathrm{Sc}$ and $\mathrm{V} / \mathrm{Ga}$ derive from partial melting under different $f \mathrm{O}_{2}$ conditions rather than other processes causing relative fractionation. The relative partitioning of $\mathrm{V}$ and $\mathrm{Sc}$ at least between clinopyroxene and silicate melt also does not seem to be influenced by pressure (Li, 2018). Modelling by Lee et al. (2005) indicates that the V/Sc of residual peridotite will decrease with partial melting when $f \mathrm{O}_{2}$ is $\geq 1$ log unit below the fayalite-magnetite-quartz (i.e. $\geq \mathrm{FMQ}-1$ ) reference oxygen buffer. Under more reducing conditions V/Sc will increase as V becomes more compatible than Sc in clinopyroxene and spinel.

We have undertaken a study of V, Sc and Ga contents in clinopyroxene from a suite of well-characterised spinel peridotite xenoliths from the Massif Central, France (UenverThiele et al., 2014, 2017). Some samples exhibit little or no evidence of metasomatism, while others have been strongly metasomatised by a variety of different agents. For all samples, oxidation states have already been determined by spinel oxybarometry using $\mathrm{Fe}^{3+}$ contents measured by Mössbauer spectroscopy (Uenver-Thiele et al., 2014). Although we do not have

1. Goethe-Universität, Frankfurt am Main, Germany

*orresponding author (email: Woodland@em.uni-frankfurt.de) 
bulk concentrations to estimate $\mathrm{fO}_{2}$ independently, elemental concentrations in clinopyroxene can provide insight into the geochemical behaviour of these trace elements in the subcontinental lithospheric mantle (SCLM). On the other hand, the $\mathrm{Fe}^{3+}$ contents of clinopyroxene were also measured for a subset of samples, allowing application of the clinopyroxene-based oxybarometer of Luth and Canil (1993) to test whether clinopyroxene and spinel are in $\mathrm{Fe}^{3+}-\mathrm{Fe}^{2+}$ redox equilibrium. $\mathrm{V}$ and other trace element concentrations are then discussed in this context, including their behaviour during metasomatism.

\section{Samples}

The samples are spinel lherzolites and harzburgites from 36 localities across the Massif Central, France. Uenver-Thiele et al. (2017) divided the samples into four groups (A, B, C, D) based upon the REE signatures of clinopyroxene, which reflect different styles of metasomatic interaction. Locality, rock type, and REE signature of clinopyroxene are summarised in the Supplementary Information (Table S-1). Group A has mildly depleted to flat patterns, indicating minor metasomatic effects. Group B exhibits LREE enrichment with La/Ce between 0.4 and 1.4 and $\mathrm{Nd} / \mathrm{Yb}$ ranging from 2 to 11 (Uenver-Thiele et al., 2017). Group C clinopyroxene is enriched in both LREE and MREE, with $\mathrm{Nd} / \mathrm{Yb}=5-35$, but limited variation in $\mathrm{La} / \mathrm{Ce}(0.2-0.7)$. Group D has a characteristic "tick-shape" REE pattern, with MREE depletion $(\mathrm{Nd} / \mathrm{Yb}<1.5)$, but strong LREE enrichment $(\mathrm{La} / \mathrm{Ce}=0.6-2)$. Each group is further characterised by other elemental enrichments or depletions and the reader is referred to Uenver-Thiele et al. (2017) for a thorough description. Some samples from groups B and C have Lu/Hf systematics interpreted as indicating a secondary origin for the clinopyroxene rather than just being overprinted.
While group D clinopyroxenes are considered to have interacted with oxidised subduction zone fluids, the signatures of groups B and C were interpreted by Uenver-Thiele $e t$ al. (2017) to have been affected by carbonatitic and carbonated mafic silicate melts (group C), as well as by mafic silicate melts (group B and some group A). In some samples, multiple metasomatic events by different agents are apparent.

\section{Oxybarometry Using $\mathrm{Fe}^{3+}-\mathrm{Fe}^{2+}$ Equilibria}

The oxidation state of spinel peridotite is most often determined using the olivine-orthopyroxene-spinel equilibrium (e.g., Wood et al., 1990; see Supplementary Information). Alternatively, Luth and Canil (1993) calibrated several olivine-orthopyroxene-clinopyroxene equilibria for estimating oxidation state based on the $\mathrm{Fe}^{3+}$ content of clinopyroxene (see Supplementary Information). For a subset of samples $(\mathrm{N}=46)$, $\Delta \log \mathrm{fO}_{2}$ values were obtained from both spinel-based and clinopyroxene-based oxybarometers and are compared in Figure 1. The two oxybarometers agree within their uncertainties ( $\pm 0.8 \log$ units; see Supplementary Information), implying redox equilibrium generally exists among the four main mantle phases, most specifically in terms of $\mathrm{Fe}^{3+}$ contents of spinel and clinopyroxene.

Ranging from FMQ-0.3 to FMQ+1.6 for spinel-based and FMQ-0.7 to FMQ+1.2 for clinopyroxene-based equilibria (Table S-1), $\Delta \log f \mathrm{O}_{2}$ values for our suite are relatively oxidised compared to the global average for non-cratonic SCLM of FMQ-0.68 (Foley, 2011). This high $\mathrm{fO}_{2}$ is attributable to various types and degrees of metasomatic interactions, with the highest $\mathrm{fO}_{2}$ correlating with the strongest LREE enrichments in clinopyroxene (Uenver-Thiele et al., 2014, 2017).

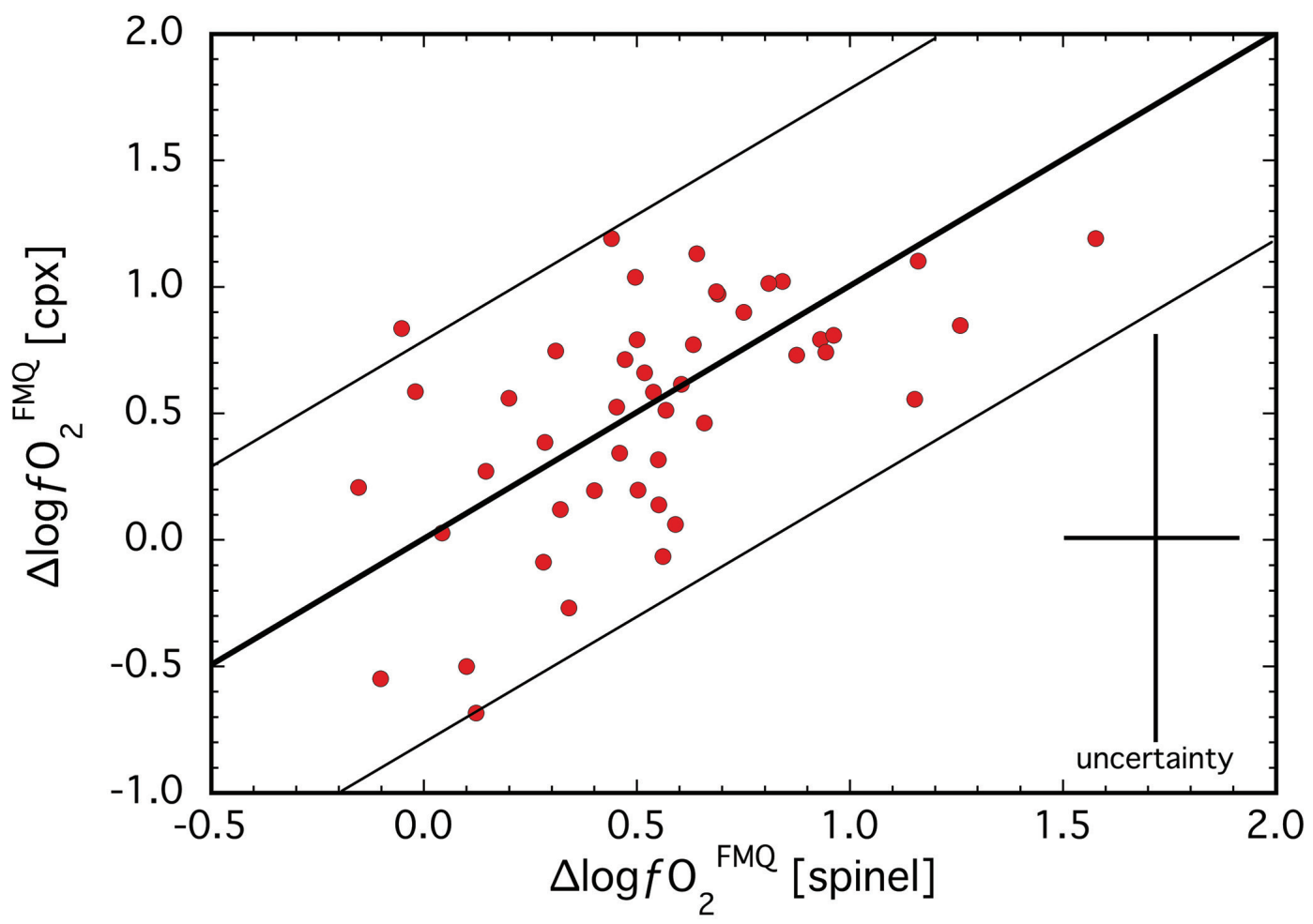

Figure 1 Comparison of $\Delta \log \mathrm{fO}_{2}$ determined from spinel-based and clinopyroxene-based $\mathrm{Fe}^{3+}-\mathrm{Fe}^{2+}$ equilibria (see Supplementary Information). The 1:1 correlation line is shown for reference, along with the estimated uncertainty of the clinopyroxene-based oxybarometer of $\pm 0.8 \mathrm{log}$ units (Luth and Canil, 1993). 


\section{The Redox Proxies V/Sc, V/Ga and V/Y}

Clinopyroxene in our suite contains $170-310 \mu \mathrm{g} / \mathrm{g} \mathrm{V}$ and 40-90 $\mu \mathrm{g} / \mathrm{g}$ and 1.5-6.5 $\mu \mathrm{g} / \mathrm{g}$ Sc and Ga, respectively (Table S-1). In Figure 2, V/Sc and V/Ga are plotted against $\Delta \log f \mathrm{O}_{2}$. The spinel-based oxybarometer was used since it is a more robust measure of $\mathrm{fO}_{2}$ with smaller uncertainties. A broad decrease in V/Sc is observed with increasing $\Delta \log f \mathrm{O}_{2}$, with clinopyroxenes belonging to groups $\mathrm{B}, \mathrm{C}$ and $\mathrm{D}$ tending to have lower ratios than those from group A (Fig. 2a). Given the number of data points $(n=247)$ and the correlation coefficient $(r=0.49)$, there is $<0.05 \%$ probability that the two parameters are not correlated. Thus, the correlation is considered to be statistically "highly significant" (e.g., Taylor, 1982). Some scatter is due to variable element concentrations between clinopyroxene grains from the same sample (Table S-1). However, a link does exist between the oxidation state recorded by $\mathrm{Fe}^{3+}-\mathrm{Fe}^{2+}$ equilibrium and V/Sc. On the other hand, a correlation between V/Ga and $\Delta \log f \mathrm{O}_{2}$ is less clear, although clinopyroxene from group A tends to higher $\mathrm{V} / \mathrm{Ga}$ with increasing $\mathrm{fO}_{2}$ (Fig. 2b). This is not the case for clinopyroxene from more metasomatised samples (groups B, C and D). Such varied behaviour of V/Sc and V/Ga cannot be attributed to subsolidus re-equilibration (i.e. WittEickschen and $\mathrm{O}^{\prime}$ Neill, 2005) since both relatively oxidised and reduced samples (and those with low and high V/Sc) exhibit a similar range in equilibration temperature (Uenver-Thiele $e t$ al., 2014). Thus, understanding these differences in geochemical behaviour requires consideration of the potential effects of metasomatic interactions.
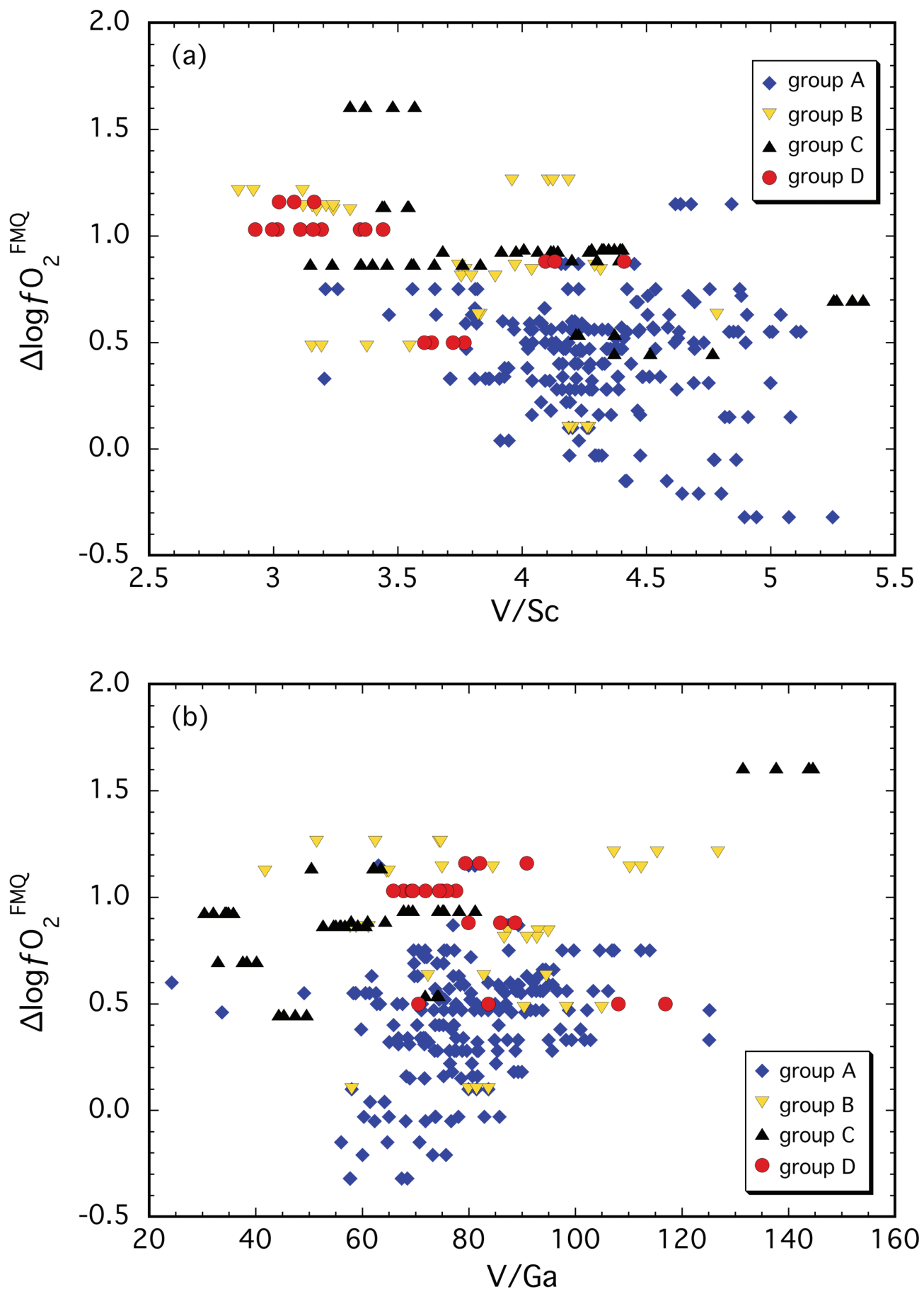

Figure 2 (a) $\mathrm{V} / \mathrm{Sc}$ and (b) $\mathrm{V} / \mathrm{Ga}$ of clinopyroxene plotted as a function of $\Delta \log \mathrm{fO}_{2}$ determined by spinel-based Fe ${ }^{3+}-\mathrm{Fe}^{2+}$ oxybarometry (see Supplementary Information). 


\section{Systematics with $\mathrm{Sc}, \mathrm{Ga}$ and $\mathrm{Y}$ and Their Relation to Metasomatism}

The least metasomatised samples (group A) form a cluster in element-element plots (Fig. 3a-d), providing a baseline for comparing clinopyroxene compositions that are more strongly overprinted. V, Sc and Ga concentrations are 250-300 $\mu \mathrm{g} / \mathrm{g}$, $50-70 \mu \mathrm{g} / \mathrm{g}$ and $2-4.5 \mu \mathrm{g} / \mathrm{g}$, yielding V/Sc and V/Ga of 3.8-5.0 and $60-100$, respectively (Fig. 3a,b). In contrast, clinopyroxene belonging to groups $\mathrm{B}, \mathrm{C}$ and $\mathrm{D}$ exhibits variable $\mathrm{V}, \mathrm{Sc}$ and $\mathrm{Ga}$ systematics, depending on the metasomatising agent involved. Most obvious is a lower $\mathrm{V}$ concentration in virtually all these samples. In many cases, a near constant Sc content relative to group A leads to systematically lower V/Sc, particularly for group $\mathrm{B}$ and $\mathrm{D}$ clinopyroxene. $\mathrm{V}$ and $\mathrm{Sc}$ concentrations of some group $\mathrm{C}$ clinopyroxenes are both relatively depleted, maintaining a near constant V/Sc. Gallium behaves differently, with noted enrichment in some group $\mathrm{C}$ clinopyroxenes, driving $\mathrm{V} / \mathrm{Ga}$ down to $<40$. Other group $\mathrm{C}$ clinopyroxenes, as well as those of groups B and D, have V/Ga similar to the unmetasomatised (or weakly metasomatised) group A clinopyroxenes, but with decreased concentrations of both elements (Fig. 3b).

Other trace elements also exhibit variable behaviour. For example, clinopyroxenes affected by subduction fluids (group D) and alkali silicate melts (group B) underwent different extents of depletion in Y (Fig. 3c). In contrast, those influenced by carbonatitic or carbonated silicate melts (group C) can be either relatively enriched or depleted in Y, the latter having a secondary origin.

As illustrated in Figure $3 \mathrm{~d}$, where $\mathrm{Nd} / \mathrm{Yb}$ serves to distinguish between different types of metasomatised clinopyroxenes, a common feature is a systematically lower $\mathrm{V}$ concentration compared to unmetasomatised or weakly metasomatised samples. Thus, although metasomatic interactions are often associated with element enrichment, under certain conditions elements can be extracted from the mineral assemblage to the mobile phase and further transported. In the case of $\mathrm{V}$, this occurs via a variety of metasomatic agents. Selective removal of $\mathrm{V}$ during metasomatism can be understood in terms of changing solid/liquid partition coefficients. The clinopyroxene/melt partition coefficient decreases with increasing $\mathrm{fO}_{2}$ (Canil and Fedortchouk, 2000; Mallmann and $\mathrm{O}^{\prime}$ Neill, 2009). For $1300{ }^{\circ} \mathrm{C}$ and 1 bar, Mallmann and $\mathrm{O}^{\prime}$ Neill (2009) give $\mathrm{D}_{\mathrm{V}}{ }^{\text {cpx/melt }}$ of 0.83 and 0.13 at $\Delta \log f \mathrm{O}_{2}$ values of FMQ-0.5 and FMQ+2, respectively (Fig. 4). They report $\mathrm{D}_{\mathrm{V}}{ }^{\mathrm{cp}}{ }^{\mathrm{m}}$ melt increases by a factor of $\sim 2$ between 1 bar and $3 \mathrm{GPa}$, but this may be an overestimate (Davis et al., 2013). In any case, the relationship between $\mathrm{D}_{\mathrm{V}}{ }^{\mathrm{cpx}} /$ melt and $\mathrm{fO}_{2}$ depicted in Figure 4 for 1 bar is not expected to change significantly at elevated pressures as $\mathrm{V}^{4+}$ and $\mathrm{V}^{5+}$ become more important compared to $\mathrm{V}^{3+}$. Given the range in $\mathrm{fO}_{2}$ recorded in our suite of samples (shaded area in Fig. 4), the decreasing partition coefficient implies that clinopyroxene should give up some of its $\mathrm{V}$ as it re-equilibrated with a migrating $\mathrm{V}$-poor melt or fluid that is relatively oxidised (i.e. $\Delta \log f \mathrm{O}_{2} \geq \mathrm{FMQ}+1$; Fig. 4).

One exception is sample 78-LU3b that has clinopyroxene somewhat enriched in $\mathrm{V}$, modestly elevated $\mathrm{Nd} / \mathrm{Yb}$, but similar Sc, Ga and Y concentrations to unmetasomatised clinopyroxene (Fig. 3a-d). Uenver-Thiele et al. (2017) considered this sample to have been refertilised by re-assimilating silicate melt trapped within the peridotite matrix. Thus, in this case the geochemical signature represents the sum of a harzburgitic protolith and an aliquot of trapped melt, leading to an overall increased budget of incompatible trace elements.
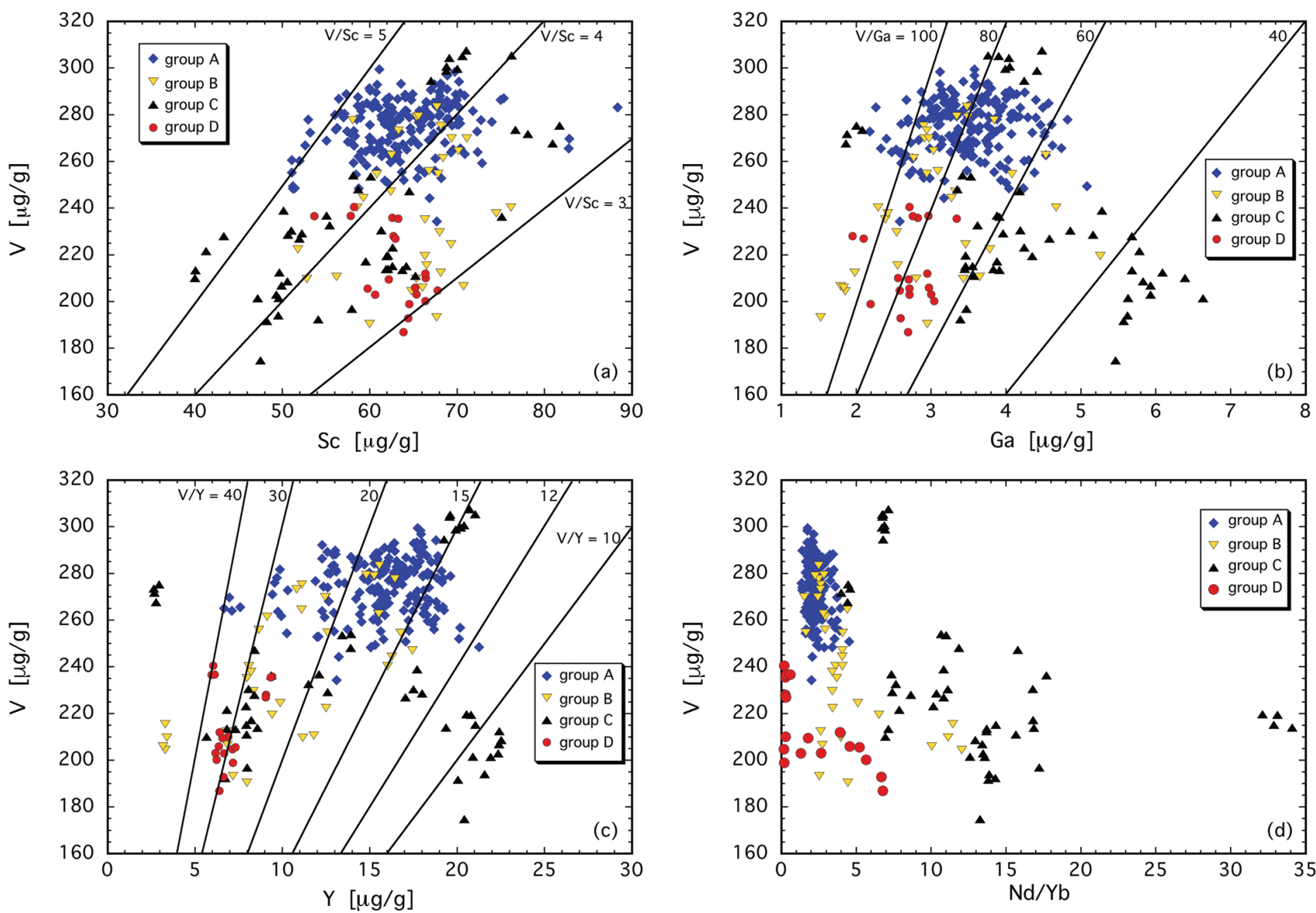

Figure 3 V concentration in different types of clinopyroxene plotted against their corresponding (a) Sc, (b) Ga and (c) Y contents, as well as (d) their $\mathrm{Nd} / \mathrm{Yb}$ ratio. 


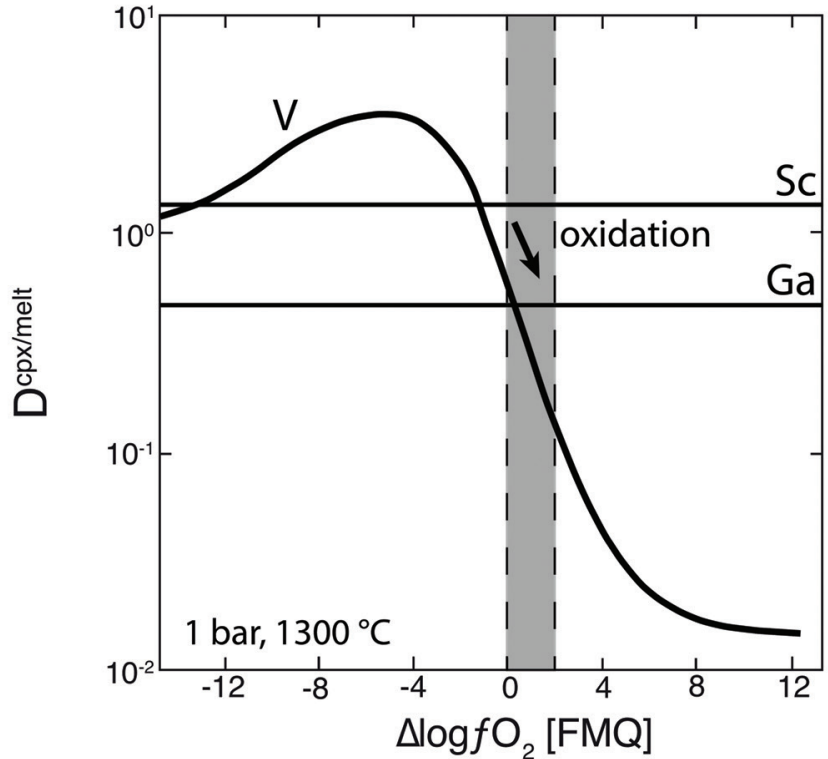

Figure 4 Variation in the clinopyroxene/silicate melt partition coefficient with $\mathrm{fO}_{2}$ at 1 bar and $1300{ }^{\circ} \mathrm{C}$, along with $\mathrm{Sc}$ and $\mathrm{Ga}$ for reference as reported by Mallmann and O'Neill (2009). The arrow emphasises the effect of oxidation on $\mathrm{D}_{\mathrm{V}}$ in the $\mathrm{fO}_{2}$ range observed in our xenolith suite from the Massif Central (shaded area). See text.

\section{Implications}

This study demonstrates that metasomatic interactions can have a direct influence on $\mathrm{V}$ concentrations in clinopyroxene. This occurs when the $f_{2}$ of the agent is different from the initial ambient peridotite. Considering that metasomatism is usually associated with oxidation (i.e. Woodland et al., 2006; Foley, 2011), modification of $V$ content might be expected to be the rule rather than the exception. However, whether or not a change is evident will depend on the extent of interaction and the relative difference in oxidation state. Note that even some group A clinopyroxenes that are less strongly overprinted also exhibit subtly lower $\mathrm{V}$ concentrations than many others from this group (Fig. 3a-d). Assuming that relative partitioning of $\mathrm{V}, \mathrm{Sc}$ and $\mathrm{Ga}$ is similar at $1 \mathrm{bar}$ and pressures corresponding to spinel peridotite facies (Li, 2018), V/Sc should decrease with increasing $\mathrm{fO}_{2}$ above FMQ as $\mathrm{D}_{\mathrm{V}}$ and $\mathrm{D}_{\mathrm{Sc}}$ diverge, but V/Ga may not vary significantly since $\mathrm{D}_{\mathrm{V}}$ and $\mathrm{D}_{\mathrm{Ga}}$ become more similar at higher $\mathrm{fO}_{2}$ (Fig. 4, Lee et al., 2005; Mallmann and O’Neill, 2009).

The nature of the metasomatising agent will also determine if other trace elements, including Sc and Ga will be added to or removed from clinopyroxene. This depends on the elemental concentrations in the agent relative to that dictated by the partition coefficient for equilibrium with peridotitic clinopyroxene. Thus, V/Sc and V/Ga can potentially shift independently of oxidation state, since the denominator element cannot necessarily be treated as immobile during metasomatism. This is illustrated by various outliers of group A clinopyroxene in Figure 3a-d that have V concentrations below $\sim 275 \mu \mathrm{g} / \mathrm{g}$ and exhibit relative addition or removal of Sc, $\mathrm{Ga}$ and Y. However, the correlation observed between V/Sc in clinopyroxene and $\mathrm{Fe}^{3+} / \mathrm{Fe}^{2+}$-based $\Delta \log \mathrm{fO}_{2}$ (Fig. 2a) indicates not only that V/Sc can be reset to reflect a changed oxidation state, but that both $\mathrm{V} / \mathrm{Sc}$ and $\mathrm{Fe}^{3+}-\mathrm{Fe}^{2+}$ equilibria can equally track such changes related to metasomatic interactions.
We have investigated the trace element behaviour only of clinopyroxene, which has not yet been calibrated to give a direct estimate of $\mathrm{fO}_{2}$ from our measured V/Sc. Although bulk-rock V/Sc is generally applied as a redox proxy (Lee et al., 2003, 2005), the $\mathrm{D}_{\mathrm{V}}-\mathrm{fO}_{2}$ systematics of clinopyroxene, olivine, orthopyroxene and spinel all exhibit the same trend of decreasing $\mathrm{D}_{\mathrm{V}}$ with increasing $\log \mathrm{fO}_{2}$ at conditions more oxidising than $\sim \mathrm{FMQ}-2$ (see Supplementary Information). In addition, the partitioning systematics of Sc among the peridotite minerals indicate that clinopyroxene should dominate the bulk Sc budget (Mallmann and O'Neill, 2009). Thus, our observations for clinopyroxene should directly mirror changes in bulk V/Sc. This implies that metasomatism can influence the bulk V/Sc of mantle peridotite, being wholly or partially reset to reflect changing oxidation states during melt/fluidrock interaction.

\section{Acknowledgements}

This manuscript benefited from discussions with A. Zeh and S. Aulbach as well as the reviews of G. Mallmann and an anonymous reviewer.

Editor: Cin-Ty Lee

\section{Additional Information}

Supplementary Information accompanies this letter at http:// www.geochemicalperspectivesletters.org/article1822.

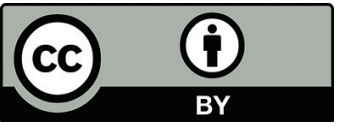

This work is distributed under the Creative Commons Attribution 4.0 License, which permits unrestricted use, distribution, and reproduction in any medium, provided the original author and source are credited. Additional information is available at http://www.geochemicalperspectivesletters.org/ copyright-and-permissions.

Cite this letter as: Woodland, A.B., Uenver-Thiele, L., Seitz, H.-M. (2018) Influence of metasomatism on vanadium-based redox proxies for mantle peridotite. Geochem. Persp. Let. 8, $11-16$.

\section{References}

CANIL, D. (2002) Vanadium in peridotites, mantle redox and tectonic environments: Archean to present. Earth and Planetary Science Letters 195, $75-90$.

CANIL, D. (2004) Mildly incompatible elements in peridotites and origins of the mantle lithosphere. Lithos 77, 375-393

CANIL, D., FedortCHOUK, Y. (2000) Clinopyroxene-liquid partitioning for vanadium and the oxygen fugacity during formation of cratonic and oceanic mantle lithosphere. Journal of Geophysical Research 105, 26003-26016.

Davis, F.A., Humayun, M., Hirschmann, M.M., CoOper, R.S. (2013) Experimentally determined mineral/melt partitioning of first-row transition elements (FRTE) during partial melting of peridotite at $3 \mathrm{GPa}$. Geochimica et Cosmochimica Acta 104, 232-260.

Foley, S.F. (2011) A reappraisal of redox melting in the Earth's mantle as a function of tectonic setting and time. Journal of Petrology 52,1363-1391.

LeE, C.-T.A., Brandon, A.D., Norman, M.D. (2003) Vanadium in peridotites as a proxy for paleo- $\mathrm{fO}_{2}$ during partial melting: prospects, limitations, and implications. Geochimica et Cosmochimica Acta 67, 3045-3064

Lee, C.-T.A., Leeman, W.P., Canil, D., Li, Z.-X. (2005) Similar V/Sc Systematics in MORB and Arc Basalts: Implications for the Oxygen Fugacities of their Mantle Source Regions. Journal of Petrology 46, 2313-2336. 
LI, Y. (2018) Temperature and pressure effects on the partitioning of $\mathrm{V}$ and Sc between clinopyroxene and silicate melt: Implications for mantle oxygen fugacity. American Mineralogist 103, 819-823.

Luth. R.W., CANIL, D. (1993) Ferric iron in mantle-derived pyroxenes and a new oxybarometer for the mantle. Contributions to Mineralogy and Petrology 113, 236-248.

Mallmann, G., O’Neill, H.St.C. (2009) The Crystal/Melt Partitioning of $\mathrm{V}$ during Mantle Melting as a Function of Oxygen Fugacity Compared with some other Elements (Al, P, Ca, Sc, Ti, Cr, Fe, Ga, Y, Zr and Nb). Journal of Petrology 50, 1765-1794.

TAYLOR, J.R. (1982) An Introduction to Error Analysis. University Science Books, Mill Valley, California, U.S.A., pp. 270

Uenver-Thiele, L., Woodland, A.B., Downes, H., Altherr, R. (2014) Oxidation state of the lithospheric mantle below the Massif Central, France. Journal of Petrology 55, 2457-2480.

Uenver-Thiele, L., Woodland, A.B., Seitz, H.-M., Downes, H. AltherR, R. (2017) Metasomatic processes revealed by trace element and redox signatures of the lithospheric mantle beneath the Massif Central, France. Journal of Petrology 58, 395-422.

WitT-Eickschen, G., O'NeILl, H.St.C. (2005) The effect of temperature on the equilibrium distribution of trace elements between clinopyroxene, orthopyroxene, olivine and spinel in upper mantle peridotite. Chemical Geology 221, 65-101.

Wood, B.J., BryndzIA, L.T., Johnson, K.E. (1990) Mantle oxidation state and its relation to tectonic environment. Science 248, 337-345.

Woodland, A.B., Kornprobst, J., TABit, A. (2006) Ferric iron in orogenic lherzolite massifs and controls of oxygen fugacity in the upper mantle. Lithos 89, 222-241. 